\title{
Thermal stress and physiological changes in watermelon seeds ${ }^{1}$
}

\author{
Rita de Cássia Barbosa da Silva², Marcelo do Nascimento Araujo², \\ Fábio Luiz Santos Ornellas ${ }^{3}$, Bárbara França Dantas ${ }^{2}$
}

\section{ABSTRACT}

Given that watermelon is a crop widespread around the world, there is considerable interest in verifying how its seeds physiologically behave under unfavorable temperature conditions. This study aimed to evaluate the biochemical changes mobilization and reserves degradation, as well as the enzyme activity, during seed germination and initial growth of watermelon seedlings subjected to thermal stress, using temperature, germination percentage, germination rate and relative germination frequency over the incubation time as evaluation parameters. The experimental design was completely randomized, in a $5 \times 3$ factorial scheme, with five temperatures $\left(17{ }^{\circ} \mathrm{C}, 20^{\circ} \mathrm{C}, 25^{\circ} \mathrm{C}, 30^{\circ} \mathrm{C}\right.$ and $\left.35^{\circ} \mathrm{C}\right)$ and three cultivars (Charleston Gray, Fairfax and Crimson Sweet), with 4 replicates of 50 seeds. Germination, seedling growth, reserve degradation and stress protection system were evaluated. Thermal stress caused deleterious effects on watermelon seeds with germination capacity at well defined temperature limits, being $25^{\circ} \mathrm{C}$ the ideal temperature, with the highest percentage of normal seedlings. Sub- $\left(17^{\circ} \mathrm{C}\right)$ and supra-optimal $\left(30^{\circ} \mathrm{C}\right)$ temperatures presented more than $80 \%$ of abnormal seedlings. The $\alpha$-amylase enzyme activity is intense only at the beginning of germination. Under thermal stress, the proline contents increase mainly in the cotyledons.

KEYWORDS: Citrullus lanatus (Thunb.) Matsum. \& Nakai; enzymatic activity; germination.

\section{INTRODUCTION}

The germination of non-dormant viable seeds, defined by technologists as germination and development of the essential structures of the embryo, resulting in the formation of a normal seedling, under favorable environmental conditions, is a biological phenomenon whose occurrence is determined by a set of specific environmental conditions. Among the environmental conditions that affect the germination

\section{RESUMO}

Estresse térmico e alterações

fisiológicas em sementes de melancia

Considerando-se que a melancia é uma cultura bem difundida no mundo, há grande interesse em verificar como suas sementes se comportam fisiologicamente sob condições de temperatura desfavoráveis. Objetivou-se avaliar as alterações bioquímicas de mobilização e degradação de reservas, bem como a atividade enzimática, durante a germinação de sementes e crescimento inicial de plântulas de melancia submetidas a estresse térmico, utilizandose temperatura, porcentagem de germinação, taxa de germinação e frequência relativa de germinação ao longo do tempo de incubação como parâmetros de avaliação. $\mathrm{O}$ delineamento experimental foi inteiramente casualizado, em esquema fatorial $5 \times 3$, com cinco temperaturas $\left(17^{\circ} \mathrm{C}, 20^{\circ} \mathrm{C}, 25^{\circ} \mathrm{C}, 30^{\circ} \mathrm{C}\right.$ e $\left.35^{\circ} \mathrm{C}\right)$ e três cultivares (Charleston Gray, Fairfax e Crimson Sweet), com 4 repetições de 50 sementes. Foram avaliados a germinação, crescimento de plântulas, degradação de reservas e sistema de proteção ao estresse. O estresse térmico causou efeitos deletérios em sementes de melancia com limites de germinação em temperaturas bem definidas, sendo $25^{\circ} \mathrm{C}$ a temperatura ideal, com o maior percentual de plântulas normais. Temperaturas sub $\left(17^{\circ} \mathrm{C}\right)$ e supraótimas $\left(30^{\circ} \mathrm{C}\right)$ apresentaram mais de $80 \%$ de plântulas anormais. A atividade da enzima $\alpha$-amilase é intensa apenas no início da germinação. Sob estresse térmico, os teores de prolina aumentam principalmente nos cotilédones.

PALAVRAS-CHAVE: Citrullus lanatus (Thunb.) Matsum. \& Nakai; atividade enzimática; germinação.

process, temperature performs a significant influence (Marcos Filho 2015).

The gradient and thermal fluctuations to which seeds are continuously exposed constitute an important signal of the environment in controlling the different stages of the plant development. In seeds, temperature acts in both dormancy induction and breaking, as well as in embryonic growth (Bewley et al. 2013).

Temperature affects the germination process in three different ways: total germination, germination

1. Manuscript received in Nov./2017 and accepted for publication in Mar./2018 (http://dx.doi.org/10.1590/1983-40632018v4850404).

2. Empresa Brasileira de Pesquisa Agropecuária (Embrapa Semiárido), Petrolina, PE, Brasil.

E-mails: cassinhauneb@yahoo.com.br, marcellomix@hotmail.com, barbara.dantas@embrapa.br.

3. Universidade Estadual de Santa Cruz, Ilhéus, BA, Brasil.E-mail: fabiolsornellas@gmail.com. 
speed and germination uniformity. Germination will only occur within certain temperature limits. Above or below this optimum temperature, there will be either reduction or non-occurrence of germination. Within these limits, there is an optimum temperature range in which the process takes place with maximum efficiency, i.e., maximum germination is obtained in the shortest time possible (Carvalho \& Nakagawa 2000).

It is also crucial to consider, in addition to the minimum, maximum and optimum temperatures, the exposure duration to these conditions. Seeds present a variable behavior, in relation to temperature, and the optimum temperature could be different for various species (Custódio et al. 2002).

The germination process is complex and involves chemical reactions and many regulatory mechanisms. In most cases, the higher the temperature, the faster the germination and more efficient the process to the extent that it may affect the biochemical reactions that determine the whole germination process (Carvalho \& Nakagawa 2000).

Insoluble high molecular reserves in seeds, such as lipids, proteins and sugars, are degraded and converted into soluble forms, which are then transported to growing tissues and used in the synthesis or energy production reactions (Buckeridge et al. 2004).

Metabolic modification results from a change in the whole biochemical process. Seeds, when subjected to stress, are the result of the activity of several enzymes involved in hydrolysis and transfer reactions, and can express the physiological quality of seeds, while the speed of use of the reserves may vary according to the species and environment (Bewley et al. 2013).

A high temperature stress may cause a serious perturbation to the membrane integrity (Waraich et al. 2012). The cell membranes integrity varies according to the degree of biochemical deterioration and/or physical damage, and may be considered the fundamental cause of changes in seed vigor (Vieira \& Kryzanowski 1999). The process of seed germination leads to enzymatic triggers able to deploy nutritional reserves for the purpose of nutrition of the embryonic axis. Starch is amongst the reserves; and for the starch reserve to be degraded and susceptible of utilization on metabolism, it must be transformed into smaller structures, such as maltose and glucose, with the action of several hydrolytic enzymes, among them $\alpha$-amylase (Buckeridge et al. 2004).
Changes and responses to thermal stress induced in the plant occur at all functional levels of the organism, which are reversible at first, but may become permanent. Even if the stress condition is temporary, the plant vitality decreases according to the stress duration (Souza et al. 2006). For this reason, this study aimed to evaluate the biochemical mobilization changes and reserves degradation, as well as the enzymatic activity, during seed germination and initial growth of watermelon seedlings submitted to thermal stress.

\section{MATERIAL AND METHODS}

The experiment was carried out at the Empresa Brasileira de Pesquisa Agropecuária (Embrapa Semiárido), in Petrolina, Pernambuco state, Brazil, in July 2011.

The experimental design was completely randomized, in a $5 \times 3$ factorial scheme, whose first factor corresponds to the temperatures $\left(17^{\circ} \mathrm{C}, 20^{\circ} \mathrm{C}\right.$, $25^{\circ} \mathrm{C}, 30^{\circ} \mathrm{C}$ and $35^{\circ} \mathrm{C}$ ) and the second to the cultivars (Charleston Gray, Fairfax and Crimson Sweet).

Four replicates of 50 seeds were placed on a paper substrate (germitest) (Brasil 2009). The paper rolls were packed in plastic bags to prevent moisture loss. Subsequently, they were taken to BOD incubators regulated at temperatures of $17^{\circ} \mathrm{C}, 20^{\circ} \mathrm{C}$, $25^{\circ} \mathrm{C}, 30^{\circ} \mathrm{C}$ and $35^{\circ} \mathrm{C}$.

The first and second germination counts were performed at 5 and 14 days after sowing - DAS (Brasil 2009), and the results expressed as average percentage of normal seedlings.

The radicle emission percentage was evaluated daily for 14 days, considering seeds with $2.0 \mathrm{~mm}$ of visible radicle. The germination evaluations allowed to calculate the average germination time (Labouriau 1983), average germination speed (Kotowski 1926) and germination speed index (Maguire 1962).

The average length of normal seedlings obtained from the sowing of four replicates of ten seeds was evaluated using a millimeter ruler. The average length of the seedlings was obtained by the sum of the measurements of each replicate at the 14th day, divided by the number of normal seedlings measured, with results expressed in centimeters (Nakagawa 1999). The shoot and root dry mass of four replicates of ten plants were separated into shoot and root systems and weighed in an analytical scale of $0.001 \mathrm{~g}$, with values expressed in grams, before 
and after drying in a greenhouse with forced air circulation at $65^{\circ} \mathrm{C}$, until constant mass.

For the biochemical assays, seed cotyledons were collected from seedlings at 1, 3 and 5 DAS (Brasil 2009) and maintained at temperatures of $17{ }^{\circ} \mathrm{C}, 20{ }^{\circ} \mathrm{C}, 25{ }^{\circ} \mathrm{C}, 30{ }^{\circ} \mathrm{C}$ and $35^{\circ} \mathrm{C}$, with cell contents extracted in potassium phosphate buffer $\left(100 \mathrm{mmol} \mathrm{L}^{-1}\right)$ at $\mathrm{pH}$ 7.0. The homogenate was centrifuged at $10.000 \mathrm{x} \mathrm{g}$ for $20 \mathrm{~min}$, at $4{ }^{\circ} \mathrm{C}$. The supernatant was removed and placed in microtubes and kept in a freezer at $-20^{\circ} \mathrm{C}$. Total soluble sugars (Morris 1948, Yemm \& Willis 1954), reducing sugars (Miller 1959) and total soluble proteins (Bradford 1976) were quantified.

The extraction and quantification of $\alpha$-amylase activity (EC 3.2.1.1) were performed according to Aragão et al. (2003) and the determination of proline content was conducted based on the methodology described by Bates (1973).
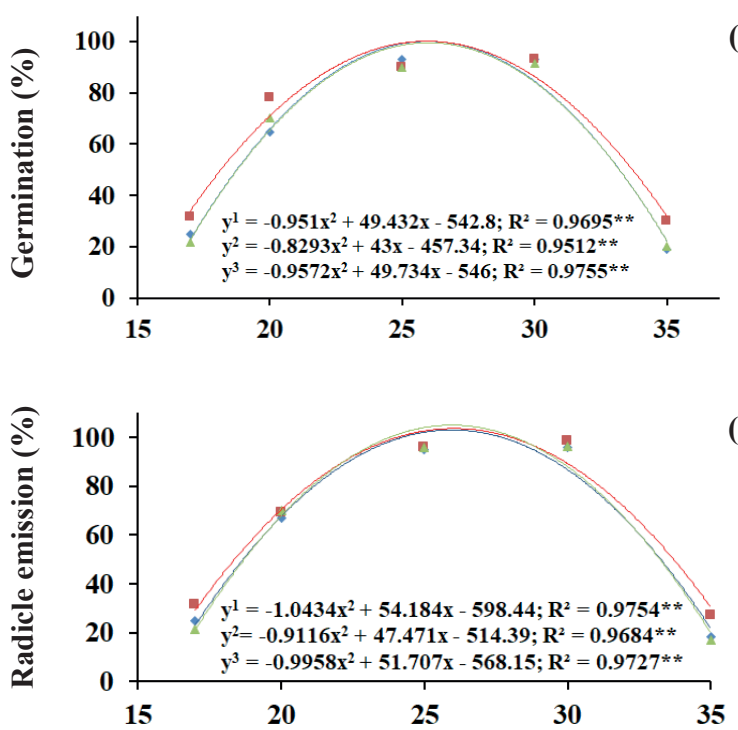

(b)

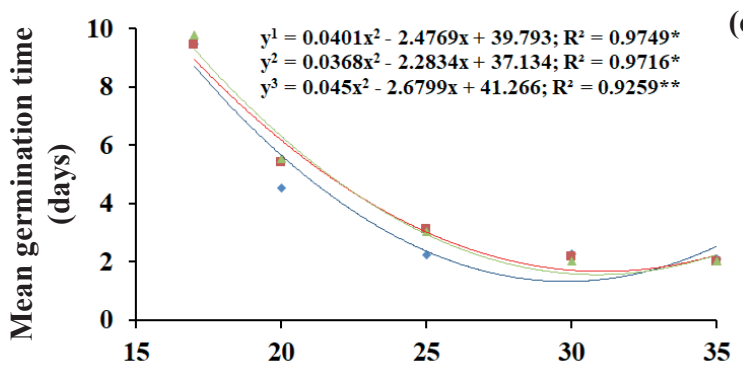

(c)

The data obtained for germination and initial growth were submitted to variance analysis and the means compared by regression analysis at a 0.05 significance.

\section{RESULTS AND DISCUSSION}

The results showed significant effects of the interaction between cultivar and temperature for all variables, germination, germination kinetics, reserves degradation and mobilization, $\alpha$-amylase activity and proline amino acid content. Regardless of the variety evaluated, there was a difference among the temperatures (Figure 1a); and the percentage of normal seedlings gradually increased from $17{ }^{\circ} \mathrm{C}$ to $25^{\circ} \mathrm{C}$. Thus, at the lowest temperature $\left(17^{\circ} \mathrm{C}\right)$, germination was between $21 \%$ and $31 \%$, while, at the highest temperature $\left(35^{\circ} \mathrm{C}\right)$, germination was delayed, but not interrupted. Sub- $\left(17{ }^{\circ} \mathrm{C}\right)$ and super-optimal $\left(35^{\circ} \mathrm{C}\right)$ temperatures presented $100 \%$ and over $80 \%$ of abnormal seedlings, respectively. The temperature of $25^{\circ} \mathrm{C}$ provided the highest percentage of normal seedlings and greater and faster germination, being considered the optimal temperature for germination of watermelon seeds in the three cultivars under study.

Thermal stress influenced the radicle emission of the watermelon seeds (Figure 1b), mainly at
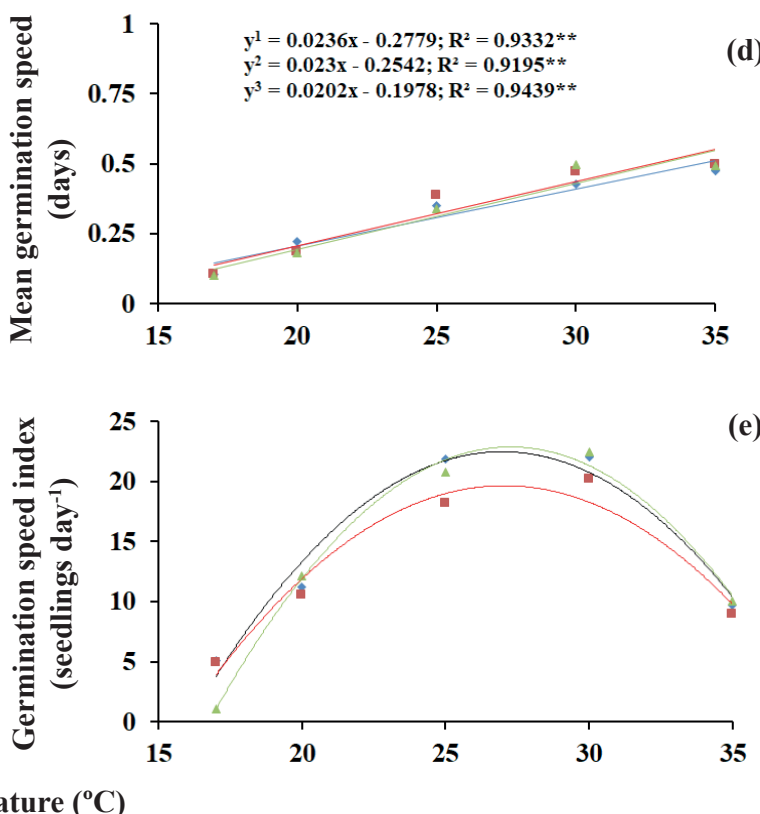

(e)

Temperature $\left({ }^{\circ} \mathrm{C}\right)$

Figure 1. Germination, radicle emission, mean germination time, mean germination speed and germination speed index of three watermelon cultivars [Charleston Gray (green); Fairfax (red); Crimson Sweet (blue)] submitted to different temperatures. ** Significant at $1 \%$. 
temperatures of $17^{\circ} \mathrm{C}$ and $20^{\circ} \mathrm{C}$, where germination was delayed because of the low temperatures and, consequently, slow imbibition. In turn, at $25{ }^{\circ} \mathrm{C}$ and $30{ }^{\circ} \mathrm{C}$, a higher radicle emission percentage was observed.

As the temperature increased, there was a reduction in the average germination time (Figure 1c), and thus, at the minimum temperature $\left(17^{\circ} \mathrm{C}\right)$, the watermelon seeds showed an average germination time of approximately nine days. In turn, under the maximum temperatures of $30^{\circ} \mathrm{C}$ and $35^{\circ} \mathrm{C}$, they had an average time of two days.

The average germination speed increased according to the increase in temperature (Figure 1d). Thus, slower germination rates are in the range between $17^{\circ} \mathrm{C}$ and $20^{\circ} \mathrm{C}$, whereas the range between $30^{\circ} \mathrm{C}$ and $35^{\circ} \mathrm{C}$ is considered optimal for these cultivars.

The germination index showed a similar behavior to the average germination speed, increasing as temperature increased (Figure 1e).

As for shoot and root length, the shoot and root dry mass could not be evaluated at the maximum temperature of $35^{\circ} \mathrm{C}$, because, at $14 \mathrm{DAS}$, the seedlings were dead, rotten and with an intense attack of fungi.

In relation to shoot length, the values were similar among the cultivars, varying from
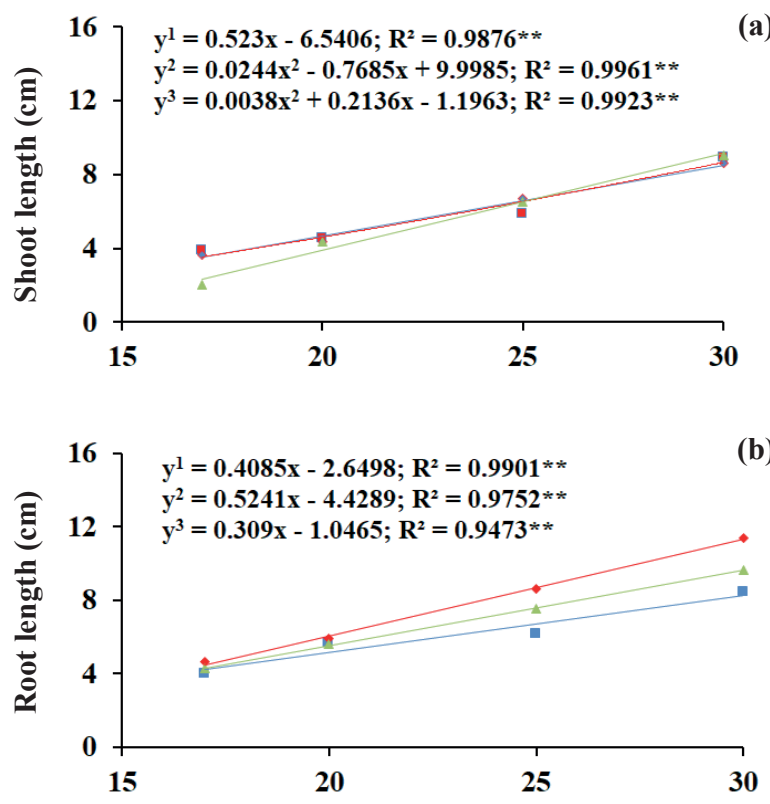

approximately $3.0 \mathrm{~cm}$ to $9.0 \mathrm{~cm}$, at temperatures of $17^{\circ} \mathrm{C}$ to $30^{\circ} \mathrm{C}$, respectively (Figure $2 \mathrm{a}$ ).

All cultivars presented the same behavior for root length (Figure $2 b$ ), increasing the average values as temperature increased. When the watermelon seeds were subjected to a temperature of $30^{\circ} \mathrm{C}$, these values were higher than the others, presenting the highest root lengths for the cultivars Fairfax, Charleston Gray and Crimson Sweet, respectively.

The watermelon cultivars Charleston Gray and Fairfax presented a similar behavior, regarding the shoot dry mass (Figure 2c), showing a greater difference for the temperature of $30^{\circ} \mathrm{C}$, in which the results were inferior to $20^{\circ} \mathrm{C}$ and $25^{\circ} \mathrm{C}$. Lower shoot dry mass values were observed for the Crimson Sweet cultivar at all temperatures.

Regarding the root dry mass, the cultivars presented a similar performance (Figure 2d), and the highest and lowest temperatures provided the lowest amounts of root dry mass, showing that thermal stress, besides affecting the germination process, also affects the growth and development of watermelon seedlings. For the three cultivars, the temperature of $25^{\circ} \mathrm{C}$ yielded the largest amount of root dry mass.

As it can be observed, the average sugar content of the cotyledons did not differ significantly

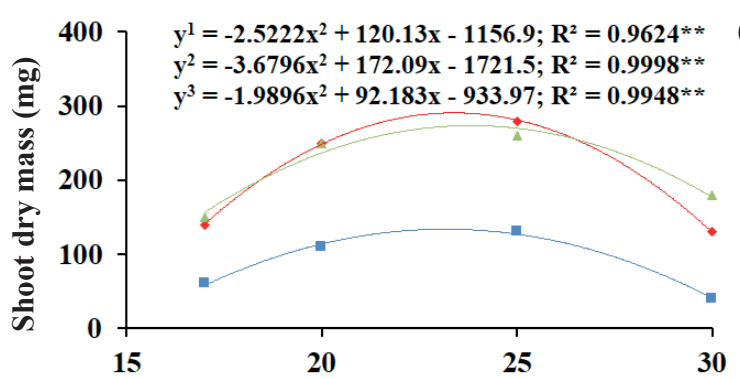

(c)

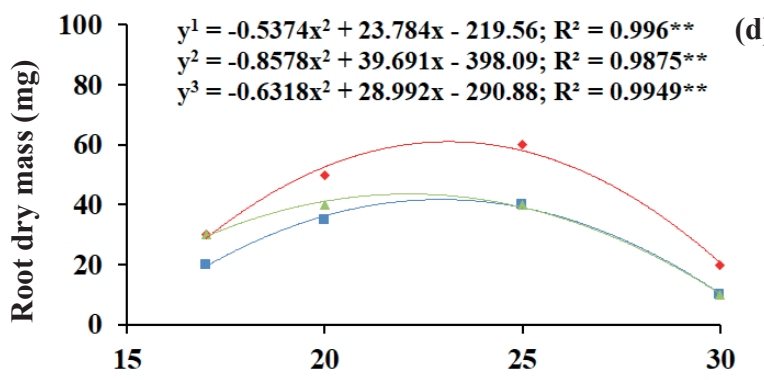

(d)

Figure 2. Shoot length (a), root length (b), shoot (c) and root (d) dry mass of three watermelon cultivars [Charleston Gray (green); Fairfax (red); Crimson Sweet (blue)] subjected to different temperatures. ** Significant at $1 \%$. 
between cultivar and temperature, during the imbibition period (Figure 3), but from radicle protrusion to the seedling stage.

The total soluble sugar contents decreased in the cotyledons for all varieties during the initial germination stage, increasing later (Figure 4). It is possible to observe that there is a greater accumulation of total soluble sugars at the temperature of $25^{\circ} \mathrm{C}$ and that the stresses caused by the smallest and highest temperatures present smaller amounts of carbohydrates, respectively.

The $\alpha$-amylase enzyme activity increased at the beginning of the germination process up to 3 DAS, at all temperatures, decreasing at 5 DAS, as the germination process progressed (Figure 5).

The average protein content in the cotyledons changed during the germination process for the three cultivars. An increase was observed during the imbibition and radicle emission, with a consequent reduction in the period of seedling formation (Figure 6). As temperature increased, there was also an increase in the total protein content, since at the temperature of $30^{\circ} \mathrm{C}$ the highest values were observed, and at $20{ }^{\circ} \mathrm{C}$ the lowest values were observed.

With the increase in temperature, there was an expressive increase, especially up to $25^{\circ} \mathrm{C}$, in the proline contents of the cotyledons collected at $5 \mathrm{DAS}$, showing the same trend for the cultivars Charleston Gray (Figure 7a), Fairfax (Figure 7b) and Crimson Sweet (Figure 7c). The proline concentration also increased in embryonic axes with the increase in temperature, but its content was lower than that of the cotyledon for all cultivars.

The optimum temperature provides the maximum germination percentage and speed (Oliveira et al. 2014, Pinheiro et al. 2014). Low temperatures delay the metabolic rate to a point where reactions that are essential to the onset of germination would no longer occur, drastically compromising this process and in less time. On the other hand, high temperatures cause a thermal stress to the seeds,

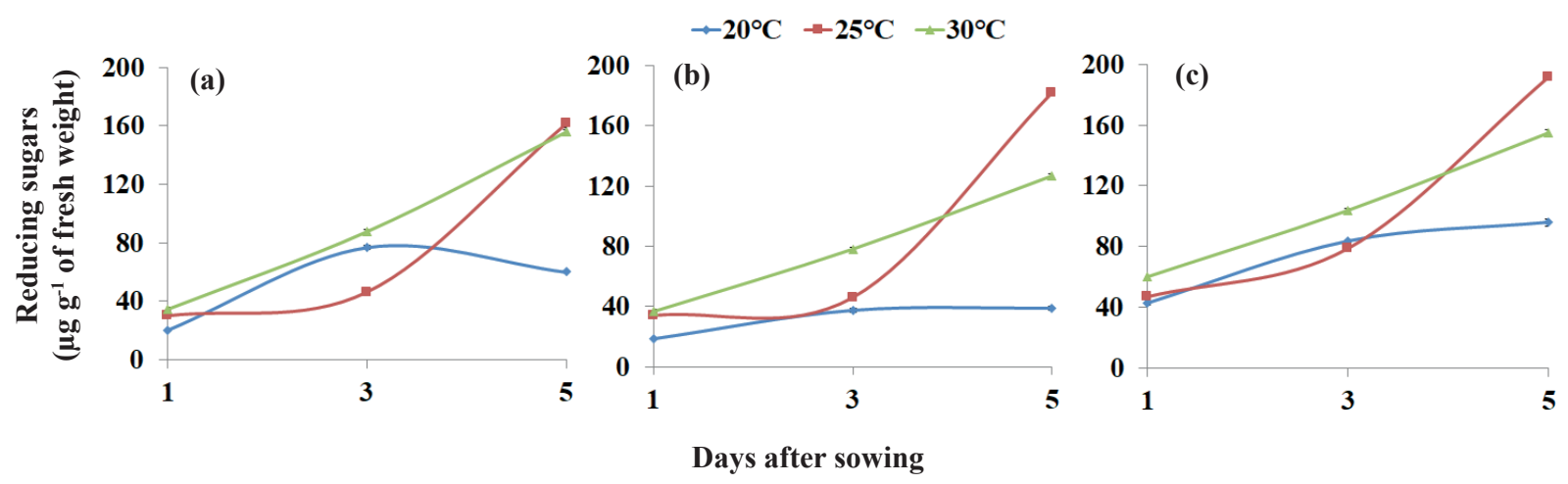

Figure 3. Amount of reducing sugars in the cotyledon at one, three and five days after sowing of watermelon seeds (Citrullus lanatus) of the Charleston Gray (a), Fairfax (b) and Crimson Sweet (c) cultivars subjected to thermal stress.

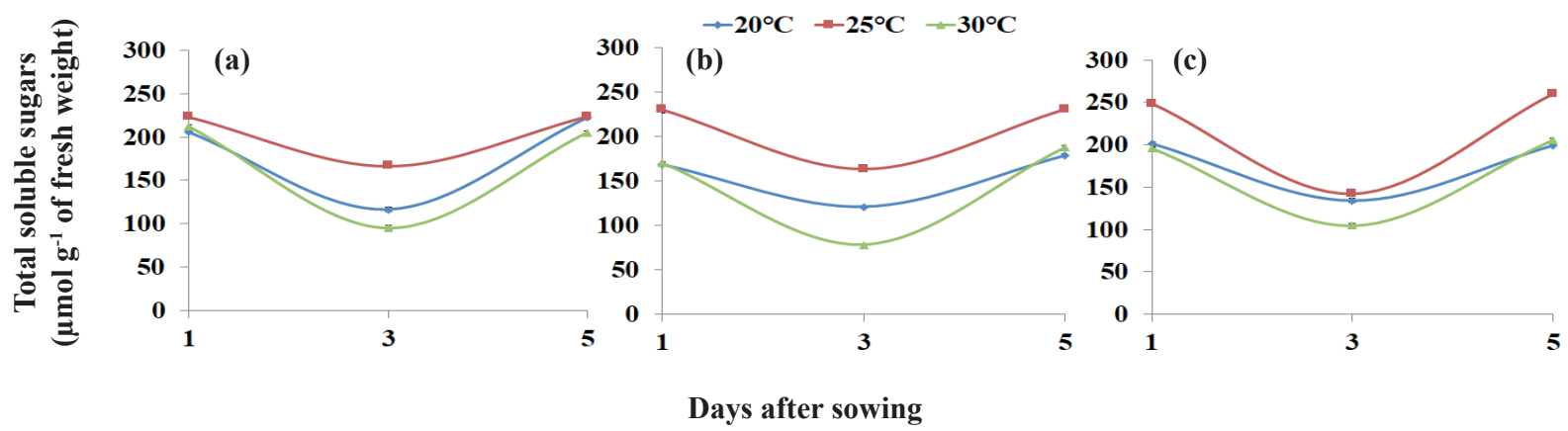

Figure 4. Amount of total soluble sugars in the cotyledon at one, three and five days after sowing of watermelon seeds (Citrullus lanatus) of the Charleston Gray (a), Fairfax (b) and Crimson Sweet (c) cultivars subjected to thermal stress. 
leading to thermal inhibition, thermal dormancy or even loss of viability (Bewley et al. 2013). In the present experiment, the seeds showed a maximum germination percentage and speed at intermediate temperatures, with low values at extreme (high and low) temperatures. This large temperature range may contribute to a better adaptation of these cultivars to variable environments.

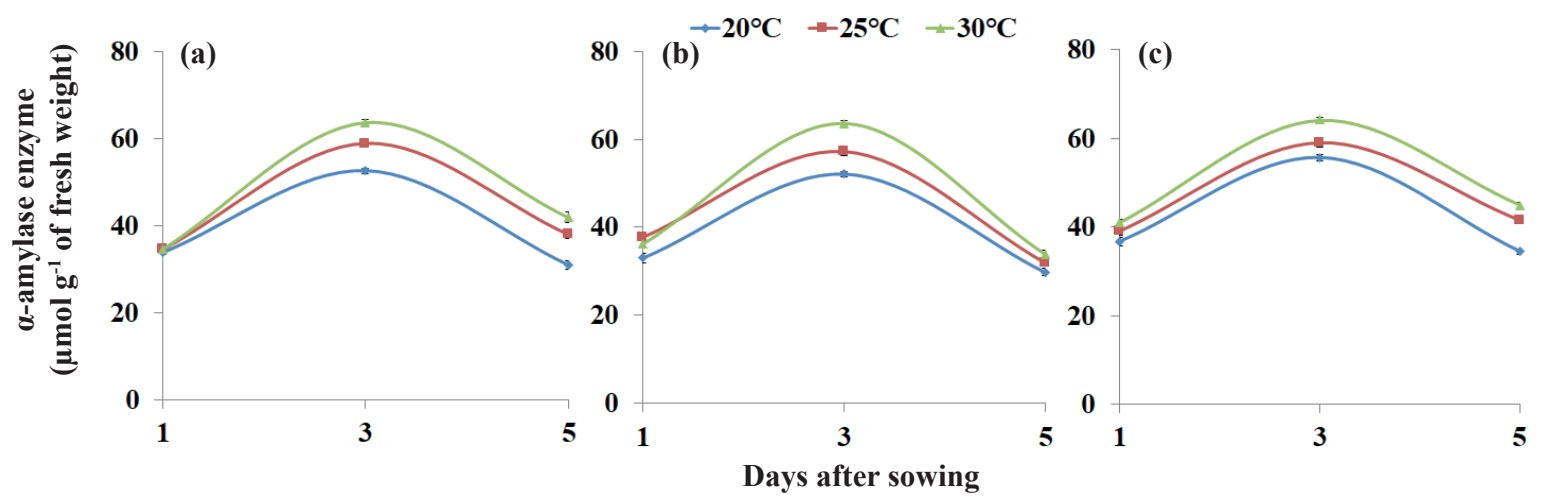

Figure 5. Activity of the $\alpha$-amylase enzyme on the cotyledon at one, three and five days after sowing of watermelon seeds (Citrullus lanatus) of the Charleston Gray (a), Fairfax (b) and Crimson Sweet (c) cultivars subjected to thermal stress.

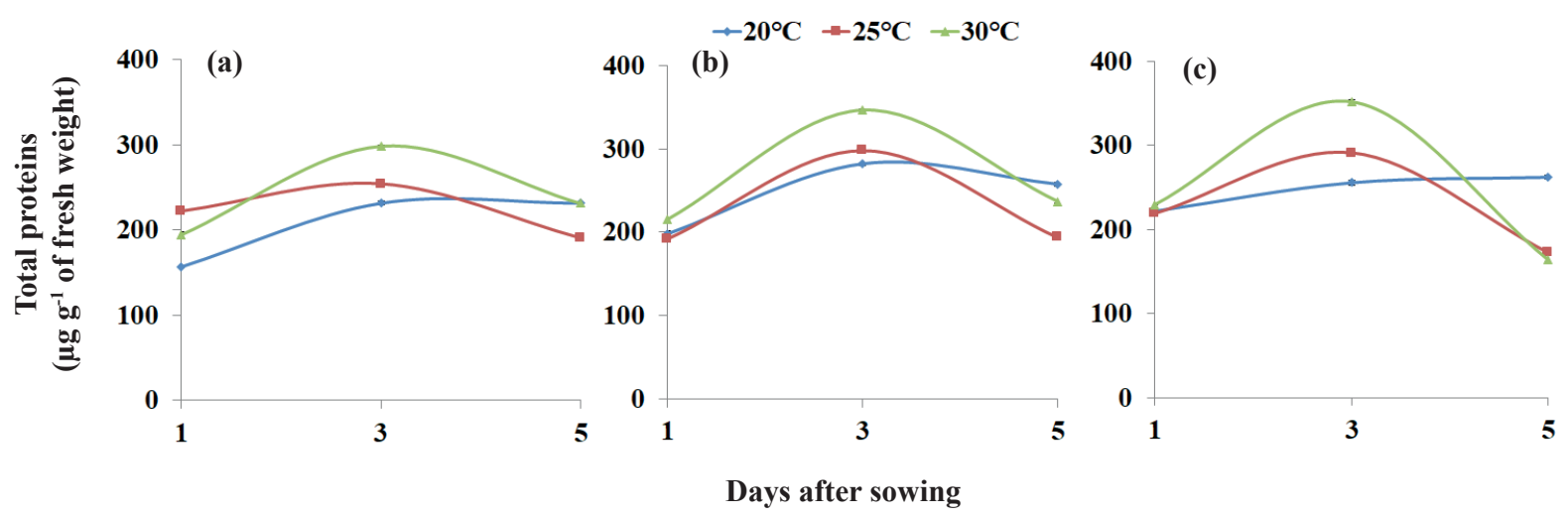

Figure 6. Amount of total proteins in the cotyledon at one, three and five days after sowing of watermelon seeds (Citrullus lanatus) of the Charleston Gray (a), Fairfax (b) and Crimson Sweet (c) cultivars subjected to thermal stress.

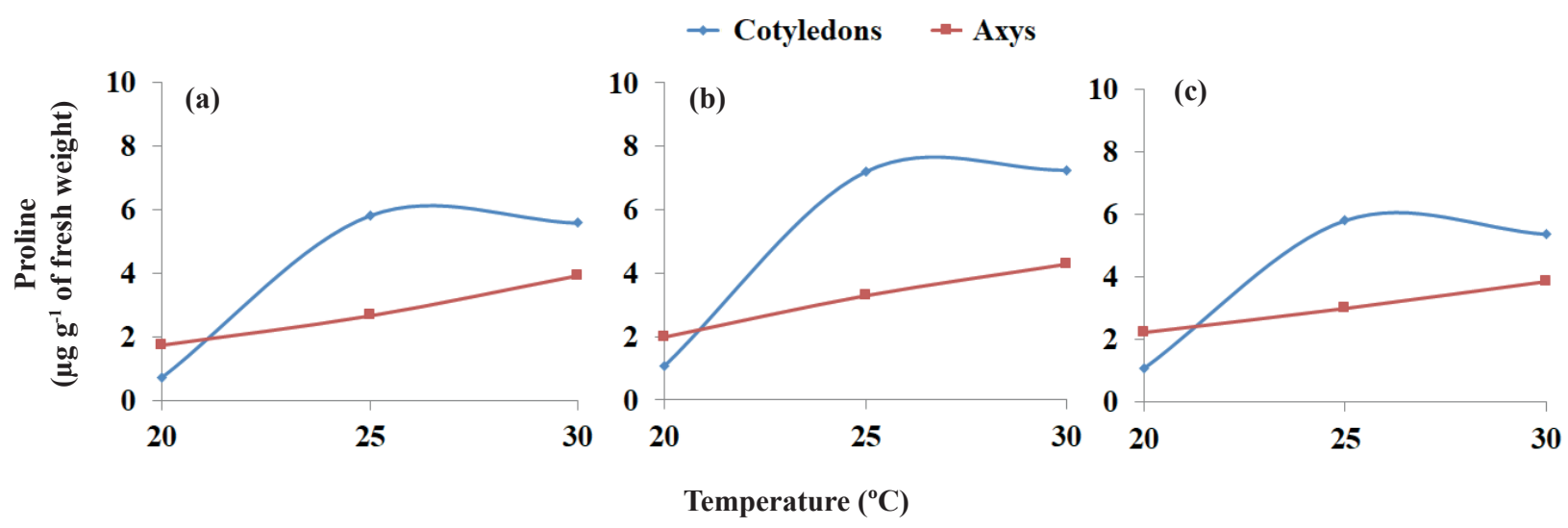

Figure 7. Amount of proline in the cotyledon (blue) and axis (red), at five days after sowing watermelon seeds (Citrullus lanatus) of the Charleston Gray (a), Fairfax (b) and Crimson Sweet (c) cultivars subjected to thermal stress. 
Regarding root emission, at $30^{\circ} \mathrm{C}$, a primary root started to be emitted, but its subsequent development was limited, followed by deterioration of the seeds, release of exudates in the germinative medium and fungal growth on the roots surface. This fact may be explained by the high temperatures, which contribute to the deterioration of the seeds, as observed by Silva Bello et al. (2008) in cherry seeds, at $40{ }^{\circ} \mathrm{C}$. Radicle emission was not negatively affected at $25^{\circ} \mathrm{C}$.

As for the average germination time, when seeds are imbibed at sub-optimal temperatures, such as $15^{\circ} \mathrm{C}$ and $20^{\circ} \mathrm{C}$, injuries may occur due to thermal stress, probably related to the damages caused in the membrane system, which disturb the seed germination and seedling establishment (Filgueira 2000). Within the $25{ }^{\circ} \mathrm{C}$ temperature range, germination speed is more orderly; and above or below this range, the values increase or decrease significantly.

At $17{ }^{\circ} \mathrm{C}$, a minimum speed index was observed, and, at $30^{\circ} \mathrm{C}$ and $35^{\circ} \mathrm{C}$, a maximum speed index was evident; however, the temperature of $25^{\circ} \mathrm{C}$ showed an intermediate speed index. Although the germination was stimulated at temperatures higher than $25^{\circ} \mathrm{C}$, the germination process was subsequently inhibited, abruptly preventing the formation of normal seedlings and favoring seed deterioration by the presence of fungi. At these elevated temperatures, the formation of abnormal seedlings, characterized by a great occurrence of weak and/or atrophied roots, was observed. The temperature of $25^{\circ} \mathrm{C}$ is the most adequate for this variable.

At lower temperatures $\left(17^{\circ} \mathrm{C}\right.$ and $\left.20^{\circ} \mathrm{C}\right)$, the root growth of the cultivars was affected, showing the lowest plant heights (average of $3.0 \mathrm{~cm}$ ), differing from the temperature of $30^{\circ} \mathrm{C}$, at which all cultivars had longer shoots $(9.0 \mathrm{~cm})$. This reduction in growth at low temperatures may be attributed to the inhibition of the enzyme activity in the seedling metabolism (Sassenrath \& Ort 1990), respiratory rate reduction (Berry \& Raison 1981), decrease in the photo-assimilate translocation in the phloem (Giaquinta \& Geiger 1973) and direct and differential effect of low temperature on cell expansion, which would be reduced by the effect of cold on the cell wall, thus increasing its stiffness (Pollock 1990).

The highest root lengths, when watermelon seeds were subjected to a temperature of $30^{\circ} \mathrm{C}$, were evidenced in the present study (Figure $2 b$ ), being more influenced by the temperature elevation than the total germination percentage (Figure 1a).
The decrease in shoot dry mass at elevated temperatures may be related to the fact that, with the increase in temperature, there is also an increase in breathing, given that watermelon is a $\mathrm{C}_{3}$ plant, i.e., typically sensitive to high temperatures (Taiz \& Zeiger 2004).

At $20^{\circ} \mathrm{C}$, the reducing sugar contents increase from imbibition until primary root emission and decrease when forming the seedling, and, at $30^{\circ} \mathrm{C}$, there is only an increase trend. In turn, at $25^{\circ} \mathrm{C}$, these contents are practically constant until the radicle emission stage, increasing significantly during seedling formation to the days after sowing, with a tendency of mobilization of these reserves during this period. This accumulation of sugars is a common feature in the cells of organisms under increases of temperature or actually stressed, since sugars have a role in osmotic adjustment, and also have indirect protective effects, such as protein stabilization (Bianchi et al. 1991).

There was a decrease and a subsequent increase in the total soluble sugar contents in the cotyledons (Figure 4). It is also possible to observe that there is a greater accumulation of total soluble sugars at the temperature of $25{ }^{\circ} \mathrm{C}$. Apparently, the mobilization of these reserves occurs after the radicle protrusion, as shown by Sassaki \& Felippe (1992). As the reserves in storage organs are mobilized, they are converted into forms that are readily transportable to sites of need (usually growing organs). Reserve mobilization decreases as the seedling emerges above the soil and becomes photosynthetically active (Bewley et al. 2013).

As regards the $\alpha$-amylase enzyme activity with the increase at the beginning of the germination process, the highest enzyme activity occurred at three days and the lowest at five days after germination, possibly due to the depletion of the starch reserves in the endosperm of the seeds. It is thus verified that $\alpha$-amylase has a high activity at the beginning of the germination process, and, over time, it is reduced. This behavior is due to the reduction in the starch content as germination progresses (Bewley et al. 2013).

The decrease in the protein concentration is probably due to the mobilization of nitrogen reserves, since proteins are composed of reserves in seeds that have nitrogen in their composition. The total protein content in the seeds increased during the imbibition process, and such an increase was associated with the induction of biosynthesis of hydrolytic enzymes 
(Pontes et al. 2002) and response to temperature, given that high temperatures inactivate enzymes, change lipid conformation and de-structure proteins; as well as peptide conformation changes the destructuring of protein complexes in the cell membrane (Jansen \& Ison 1994).

In relation to the increase in amino acid proline in this study, plants alter the metabolism in various ways to accommodate environmental stresses, including thermal stress, producing osmoregulatory compounds such as the amino acid proline (Taiz \& Zeiger 2004). In general, high temperatures lead to a decrease in the amino acid supply, RNA and protein synthesis, as well as a decrease in the rate of metabolic reactions (Riley 1981), which may retard or suppress germination and even cause loss of viability.

\section{CONCLUSIONS}

1. Watermelon seeds present a germination capacity at well defined temperature limits, being $25^{\circ} \mathrm{C}$ the ideal temperature;

2 . The $\alpha$-amylase enzyme activity is intense only at the beginning of germination;

3. Stress factors owing to increased proline contents occur specifically in the cotyledons.

\section{REFERENCES}

ARAGÃO, C. A. et al. Atividade amilolítica e qualidade fisiológica de sementes armazenadas de milho super doce tratadas com ácido giberélico. Revista Brasileira de Sementes, v. 25, n. 1, p. 43-48, 2003.

BATES, L. S. Rapid determination of free proline for water stress studies. Plant and Soil, v. 39, n. 1, p. 205-207, 1973.

BERRY, J. A.; RAISON, J. K. Physiological plant ecology I: responses of macrophytes to temperature. In: LAGE, O. L. et al. (Eds.). Encyclopedia of plant physiology. Berlin: Springer-Verlag, 1981. p. 277-329.

BEWLEY, J. D. et al. Seeds: physiology of development, germination and dormancy. New York: Springer, 2013.

BIANCHI, G. et al. Novel carbohydrate metabolism in the resurrection plant Craterostigma plantagineum. The Plant Journal, v. 1, n. 3, p. 355-359, 1991.

BRADFORD, M. M. A rapid and sensitive method for the quantitation of microgram quantities of protein utilizing the principle of protein-dye binding. Analytical Biochemistry, v. 72, n. 1-2, p. 248-254, 1976.
BRASIL. Ministério da Agricultura, Pecuária e Abastecimento. Regras para análise de sementes. Brasília, DF: MAPA/ACS, 2009.

BUCKERIDGE, M. S. et al. Mobilização de reservas. In: FERREIRA, A. G.; BORGHETTI, F. (Orgs.). Germinação: do básico ao aplicado. Porto Alegre: Artmed, 2004. p. 163-185.

CARVALHO, N. M.; NAKAGAWA, J. Sementes: ciência, tecnologia e produção. 4. ed. Jaboticabal: Funep, 2000.

CUSTÓDIO, C. C. et al. Estresse por alumínio e por acidez em cultivares de soja. Scientia Agricola, v. 59, n. 1, p. 145-153, 2002.

FILGUEIRA, F. A. R. Novo manual de olericultura: agrotecnologia moderna na produção e comercialização de hortaliças. Viçosa: UFV, 2000.

GIAQUINTA, R. T.; GEIGER, D. R. Mechanism of inibition of translocation by localized chilling. Plant Physiology, v. 51, n. 2, p. 372-377, 1973.

JANSEN, P. I.; ISON, R. L. Temperature effects on germination of Trifolium balansae and T. resupinatum with special reference to high-temperature dormancy. Australian Journal of Agricultural Research, v. 45, n. 3, p. 689-701, 1994.

KOTOWSKI, F. Temperature relations to germination of vegetable seeds. Proceedings of the American Society of Horticultural Science, v. 23, n. 1, p. 176-184, 1926.

LABOURIAU, L. G. A germinação das sementes. Washington, DC: Secretaria Geral da Organização dos Estados Unidos Americanos, 1983.

MAGUIRE, J. D. Speed of germination-aid in selection and evaluation for seedling emergence and vigor. Crop Science, v. 2, n. 2, p. 176-177, 1962.

MARCOS FILHO, J. Fisiologia de sementes de plantas cultivadas. 2. ed. Londrina: Abrates, 2015.

MILLER, G. L. Use of dinitrosalicilic acid reagent for determination of reducing sugar. Analytical Chemistry, v. 31, n. 3, p. 426-428, 1959.

MORRIS, D. L. Quantitative determination of carbohydrates with Drywood's anthrone reagent. Science, v. 107, n. 2775, p. 254-255, 1948.

NAKAGAWA, J. Testes de vigor baseados no desempenho de plântulas. In: KRZYZANOWSKI, F. C.; VIEIRA, R. D.; FRANÇA NETO, J. B. (Eds.). Vigor de sementes: conceitos e testes. Londrina: Abrates, 1999. p. 1-24.

OLIVEIRA, G. M. et al. Germinação de sementes de espécies arbóreas nativas da Caatinga em diferentes temperaturas. Scientia Plena, v. 10, n. 4, p. 1-6, 2014.

PINHEIRO, G. S. et al. Efeito da temperatura sobre a germinação de sementes de cebola. Scientia Plena, v. 10, n. 11, p. 1-6, 2014. 
POLLOCK, C. J. The response of plants to temperature change. The Journal of Agricultural Science, v. 115, n. 1, p. 1-5, 1990.

PONTES, C. A. et al. Mobilização de reservas em sementes de Apuleia leiocarpa (Vogel). J. F. Macbr. (garapa) durante a embebição. Revista Árvore, v. 26, n. 5, p. 593-601, 2002.

RILEY, G. J. P. Effects of high temperature on protein synthesis during germination of maize (Zea mays L.). Planta, v. 151, n. 1, p. 75-80, 1981.

SASSAKI, R. M.; FELIPPE, G. M. Remoção dos cotilédones e desenvolvimento inicial de Dalbergia miscolobium. Revista Brasileira de Botânica, v. 15, n. 1, p. 5-16, 1992.

SASSENRATH, G. F.; ORT, D. R. The relationship between inibition of photosynthesis at low temperature and inibition of photosynthesis after rewarming in chillsensitive tomato. Plant Physiology and Biochemistry, v. 28, n. 4, p. 457-465, 1990.

SILVA BELLO, E. P. B. C. et al. Germinação de sementes de Amburana acreana (Ducke) A. C. Sm. submetidas a diferentes condições de temperatura e de estresse hídrico. Revista Brasileira de Sementes, v. 30, n. 3, p. 16-24, 2008.

SOUZA, J. R. P. et al. Ação do estresse térmico na sobrevivência de mudas e produção de camomila originadas de sementes importadas e nacionais. Horticultura Brasileira, v. 24, n. 2, p. 233-236, 2006.

TAIZ, L.; ZEIGER, E. Fisiologia do estresse. In: TAIZ, L.; ZEIGER, E. Fisiologia vegetal. Porto Alegre: Artmed, 2004. p. 613-643.

VIEIRA R. D.; KRZYZANOWSKI F. C. Teste de condutividade elétrica. In: KRZYZANOWSKI, F. C.; VIEIRA, R. D.; FRANÇA NETO, J. B. (Eds.). Vigor de sementes: conceitos e testes. Londrina: Abrates, 1999. p. 1-26.

WARAICH, E. A. et al. Alleviation of temperature stress by nutrient management in crop plants: a review. Journal of Soil Science and Plant Nutrition, v. 12, n. 2, p. 221244, 2012.

YEMM, E. W.; WILLIS, A. J. The estimation of carbohydrates in plants extracts by anthrone. Biochemical Journal, v. 57, n. 3, p. 508-514, 1954. 